\title{
DRESS after IV phenytoin associated with cytochrome P450 CYP2C9*3 homozygosity
}

Mette S. Nissen, MD, and Christoph P. Beier, MD

Neurol Genet 2018;4:e272. doi:10.1212/NXG.0000000000000272
Correspondence

Dr. Beier

cbeier@health.sdu.dk

Phenytoin is a first-generation antiepileptic drug, which is used in the treatment of focal seizures and as standard of care for patients with benzodiazepine-refractory status epilepticus. Elimination of phenytoin occurs primarily via CYP enzyme-dependent hepatic clearance. The first step is the para-hydroxylation from active phenytoin to inactive hydroxy-phenytoin, which is dependent on CYP2C9 and, to a lesser extent, on CYP2C19. A considerable disparity in CYP2C9 alleles exists, and the frequency varies among different ancestry groups, the CYP2C9*3 allele being less frequent in Caucasians and more frequent in Asian populations. ${ }^{1,2}$ Homozygosity for the CYP2C $9^{*} 3$ allele leads to a significant reduction in enzyme activity, resulting in increased plasma levels of phenytoin. ${ }^{3}$

Severe cutaneous adverse drug reactions (SCARs) such as Steven Johnson syndrome, toxic epidermal necrolysis, or drug reaction with eosinophilia and systemic symptoms (DRESS) are known complications of phenytoin treatment. The pharmacogenetic basis of SCARs due to phenytoin treatment is not yet fully understood. Certain human leukocyte antigen (HLA) subtypes (e.g., HLA-B*13:01, HLA-B*56:02/04) are associated in some Asian populations with an increased risk of developing SCARs, however, the association is less pronounced as compared to carbamazepine. ${ }^{4}$ In 2014, CYP2C9 polymorphism (CYP2C9*3) was first described as a new and highly significantly associated nonimmunologic genetic risk factor for SCARs in a Japanese population. ${ }^{4}$

\section{Case report}

Here, we report a case of DRESS after IV administered phenytoin in a patient with CYP2C9*3 homozygosity. The 54-year-old, non-consanguineous, female refugee from northern Iran (and born in Pakistan) presented to the neurologic department at the Odense University Hospital (Denmark) with a first-time bilateral tonic-clonic seizure, with subsequent series of focal seizures with impaired consciousness, fulfilling status epilepticus criteria. Treatment with $10 \mathrm{mg}$ of IV diazepam remained ineffective. Fosphenytoin $(20 \mathrm{mg}$ phenytoin-equivalents $/ \mathrm{kg})$ was administered IV, and the seizures were terminated. As per protocol, the patient received a maintenance dose of phenytoin $100 \mathrm{mg} \mathrm{q} 8 \mathrm{~h}$. MRI of the brain revealed sequela after traumatic brain injury in the left frontal lobe as likely epileptic focus; routine blood tests were normal. Two days after admission, the patient developed nystagmus, ataxia, vertigo, nausea, and universal pruritus. Blood tests revealed plasma phenytoin levels equal to phenytoin poisoning. Despite initial reduction and termination of the maintenance dose of phenytoin, plasma levels continued to increase in the following days, reaching a maximum of $142 \mu \mathrm{M}(35.8 \mu \mathrm{g} / \mathrm{mL}) 4$ days after the first administration. At day 8, the patient developed SCARs that fulfilled the RegiSCAR criteria for DRESS. ${ }^{5}$ She developed fever $\left(39.5^{\circ} \mathrm{C}\right)$, hypotension, acute rash (figure, A), leukocytosis, lever abnormalities (alanine transaminase $>400 \mathrm{U} / \mathrm{L}$ ), and lymphadenopathy. PET-CT 10 days after the start of symptoms revealed universal lymphadenopathy (figure, B), resembling lymphoma. Liver biopsy showed inflammation compatible with hepatotoxicity. Skin biopsy showed inflammation, but with no significant eosinophilia. The patient's antiepileptic treatment was changed to levetiracetam.

From the Department of Neurology (M.S.N., C.P.B.), Odense University Hospital; and Department of Clinical Research (C.P.B.), University of Southern Denmark, Odense, Denmark. Funding information and disclosures are provided at the end of the article. Full disclosure form information provided by the authors is available with the full text of this article at Neurology.org/NG.

The Article Processing Charge was funded by Free Research Grants, Odense University Hospital.

This is an open access article distributed under the terms of the Creative Commons Attribution-NonCommercial-NoDerivatives License 4.0 (CC BY-NC-ND), which permits downloading and sharing the work provided it is properly cited. The work cannot be changed in any way or used commercially without permission from the journal. 

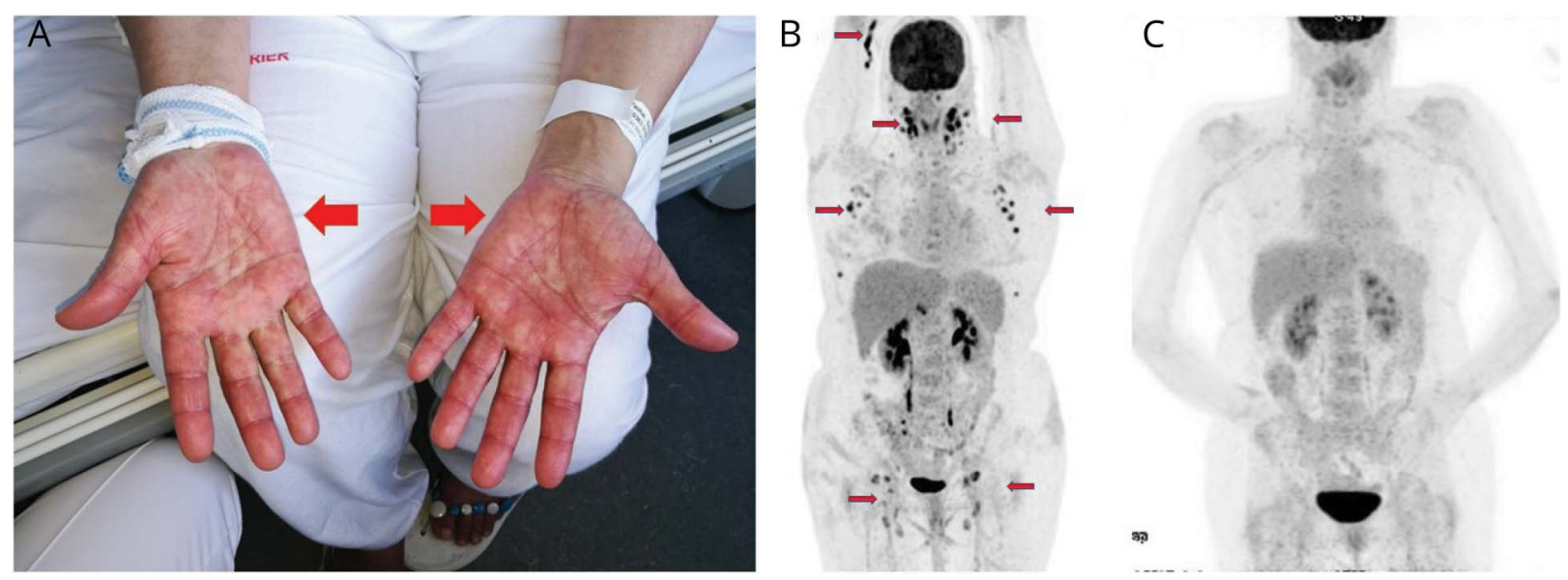

(A) The patient developed severe rash on the entire body (image taken at day 24). (B) Universal lymphadenopathy visualized by PET-CT at day 18 . (C) PET-CT 1 month after the hospital stay showed complete recovery of lymphadenopathy (58 days after admission).

After 2 weeks, the symptoms slowly started to remit as the plasma levels of phenytoin normalized, and after 4 weeks, the patient was fully recovered. A control PET-CT was performed 6 weeks after debut of the symptoms to rule out lymphoma; the lymphadenopathy had completely resolved (figure, C). Genetic testing revealed homozygosity for the $\mathrm{P} 450 \mathrm{CYP} 2 \mathrm{C} 9^{*} 3$ allele. The HLA types were HLA-A 30:68 and HLA-B 14:15.

\section{Discussion}

Plasma phenytoin levels are greatly affected by CYP2C9 polymorphisms. It is estimated that roughly $5 \%$ of the Scandinavian population are heterozygous for $\mathrm{CYP}_{2} \mathrm{C} 9^{*} 3$ allele; ${ }^{2}$ however, the prevalence is substantially higher in India and in the Middle East, where up to $16 \%$ carry a CYP2C9*3 allele, resulting in a higher proportion of homozygous patients (up to $1.6 \%$ in India $^{1}$ ). In several Asian ${ }^{4,6}$ but not in Caucasian ${ }^{7}$ populations, the CYP2C9*3 allele was associated with SCARs such as DRESS. The ethnic differences may be due to immunologic differences that are also seen in analyses focusing on HLA subtypes associated with SCARs. ${ }^{4,6,7}$ Our patient's history illustrates the impressive systemic and cutaneous side effects of phenytoin associated with CYP2C $9^{*} 3$ homozygosity in this Asian patient. It stresses the importance of being aware of interracial genetic variability that can result in substantially increased risk of intoxication and greater risk of developing severe side effects such as SCARs. For practical purposes, genetic screening before IV phenytoin treatment is not feasible. Increasing phenytoin plasma concentrations despite dose reductions, as seen in this patient, has to prompt precaution and eventually rapid change of the antiepileptic treatment. In patients with established homozygosity for the P450 CYP2C9*3 allele, phenytoin treatment should be avoided.

\section{Author contributions}

M.S. Nissen and C.P. Beier treated the patient and wrote and finally approved the manuscript.

\section{Study funding}

The study was supported by the Region of Southern Denmark to C.P.B. (17/18517).

\section{Disclosure}

M.S. Nissen reports no disclosures. C.P. Beier served on the scientific advisory boards of UCB and Eisai; received speaker honoraria from UCB and Eisai; and received research support from UCB, Eisai, Novartis, Pfizer, and the Region of Southern Denmark. Full disclosure form information provided by the authors is available with the full text of this article at Neurology.org/NG.

Received April 30, 2018. Accepted in final form July 26, 2018.

\section{References}

1. Gaikwad T, Ghosh K, Shetty S. VKORC1 and CYP2C9 genotype distribution in Asian countries. Thromb Res 2014;134:537-544.

2. Pedersen RS, Verstuyft C, Becquemont L, Jaillon P, Brosen K. Cytochrome P4502C9 (CYP2C9) genotypes in a Nordic population in Denmark. Basic Clin Pharmacol Toxicol 2004:94:151-152.

3. Silvado CE, Terra VC, Twardowschy CA. CYP2C9 polymorphisms in epilepsy: influence on phenytoin treatment. Pharmacogenomics Pers Med 2018;11: $51-58$.

4. Chung WH, Chang WC, Lee YS, et al. Genetic variants associated with phenytoinrelated severe cutaneous adverse reactions. JAMA 2014;312:525-534.

5. Kardaun SH, Sekula P, Valeyrie-Allanore L, et al. Drug reaction with eosinophilia and systemic symptoms (DRESS): an original multisystem adverse drug reaction. Results from the prospective RegiSCAR study. Br J Dermatol 2013;169:1071-1080.

6. Tassaneeyakul W, Prabmeechai N, Sukasem C, et al. Associations between HLA class $\mathrm{I}$ and cytochrome P450 2C9 genetic polymorphisms and phenytoin-related severe cutaneous adverse reactions in a Thai population. Pharmacogenet Genomics 2016;26: 225-234.

7. McCormack M, Urban TJ, Shianna KV, et al. Genome-wide mapping for clinically relevant predictors of lamotrigine- and phenytoin-induced hypersensitivity reactions. Pharmacogenomics 2012;13:399-405. 


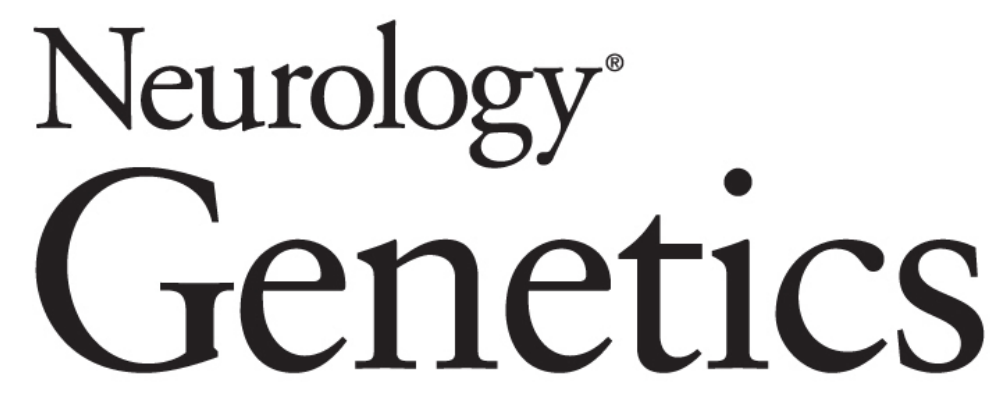

\title{
DRESS after IV phenytoin associated with cytochrome P450 CYP2C $9 * 3$ homozygosity \\ Mette S. Nissen and Christoph P. Beier \\ Neurol Genet 2018;4; \\ DOI 10.1212/NXG.0000000000000272
}

This information is current as of September 19, 2018

\begin{abstract}
Updated Information \& Services

including high resolution figures, can be found at: http://ng.neurology.org/content/4/5/e272.full.html

References

This article cites 7 articles, 0 of which you can access for free at: http://ng.neurology.org/content/4/5/e272.full.html\#\#ref-list-1

Subspecialty Collections

This article, along with others on similar topics, appears in the following collection(s):

Antiepileptic drugs

http://ng.neurology.org//cgi/collection/antiepileptic_drugs Status epilepticus

http://ng.neurology.org//cgi/collection/status_epilepticus

Permissions \& Licensing its entirety can be found online at:

http://ng.neurology.org/misc/about.xhtml\#permissions

Reprints

Information about ordering reprints can be found online: http://ng.neurology.org/misc/addir.xhtml\#reprintsus
\end{abstract}

Information about reproducing this article in parts (figures,tables) or in

Neurol Genet is an official journal of the American Academy of Neurology. Published since April 2015, it is an open-access, online-only, continuous publication journal. Copyright Copyright ( 2018 The Author(s). Published by Wolters Kluwer Health, Inc. on behalf of the American Academy of Neurology.. All rights reserved. Online ISSN: 2376-7839.

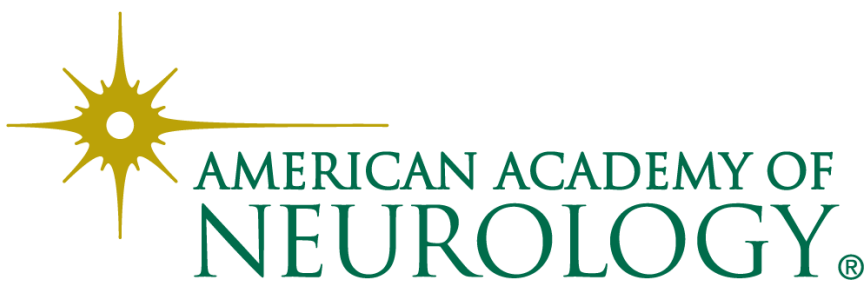

